\title{
Leaf blight and fruit rot disease of brinjal caused by Diaporthe vexans (Phomopsis vexans) in six agro-ecological regions of South West India
}

\author{
Mahadevakumar S and Janardhana GR
}

Mycology and Phytopathology Laboratory, Department of Studies in Botany, University of Mysore, Manasagangotri, Mysore-570006, Karnataka, India

Mahadevakumar S, Janardhana GR 2016 - Leaf blight and fruit rot disease of brinjal caused by Diaporthe vexans (Phomopsis vexans) in six agro-ecological regions of South West India. Plant Pathology \& Quarantine 6(1), 5-12, Doi 10.5943/ppq/6/1/2

\begin{abstract}
Diaporthe vexans associated with leaf blight and fruit rot disease of brinjal is a serious fungal pathogen causing a significant economic loss in terms of production. Leaf blight and fruit rot disease severity across six agro-ecological zones of Karnataka (India) was studied and the isolation frequency of $D$. vexans from the six regions was determined. $D$. vexans isolates were grown on potato dextrose agar medium and identified based on morphological and cultural characteristics. High severity of leaf blight disease was recorded in northern transition zone (NTZ: 10.6-25.3\%) followed by central dry zone (CDZ: 10-17\%) and southern dry zone (SDZ: $8.3-18 \%$ ). The maximum severity of fruit rot disease was in CDZ (29-39\%) followed by SDZ (22.3-62\%) and NTZ (21-33.3\%). The frequency of occurrence of D. vexans ranged from $90-100 \%$ in all the zones studied and the isolates were all similar in morphology and cultural characteristics. The study concluded that $D$. vexans is a serious constraint to brinjal production in six brinjal growing regions of southwest India.
\end{abstract}

Key words - brinjal - disease severity - identification - morpho-cultural- Phomopsis vexans Solanum melongena

\section{Introduction}

Species of Diaporthe and their asexual morphs (Phomopsis species) have broad host ranges and are widely distributed as plant parasites, endophytes and saprobes (Carroll 1986, Boddy \& Griffith 1989, Murali et al. 2006, Botella \& Diez 2011, Udayanga et al. 2011, Gomes et al. 2013). Diaporthe species are responsible for some important crop diseases worldwide including root rots, fruit rots, dieback, cankers, leaf spots, blights, decay and wilt (Mostert et al. 2001, Santos et al. 2011, Thompson et al. 2011). Endophytic Diaporthe species can deter herbivory, have lingocellulolytic activities, or act as bio-herbicides. Diaporthe vexans (asexual morph Phomopsis vexans) on brinjal, causes severe damage to the brinjal crop in different regions of the world.

Brinjal (Solanum melongena L., Solanaceae) is an agronomically important non-tuberous crop native to southern India, and widely grown in America, Europe and Asia (Sekara et al. 2007). It is one of the most important vegetable crops in India (Rashid 1976, Zeven \& Zhukovsky 1975, Sekara et al. 2007). 
Fruit rot and leaf blight disease caused by Diaporthe vexans is of major concern in brinjal producing areas of India as it reduces yield and marketable value of the crop by $20-30 \%$ (Das 1998, Khan 1999). In Karnataka, leaf blight and fruit rot disease is a major limiting factor for brinjal crop production in recent years. Hence, the present study was conducted to determine disease severity of Diaporthe in six major agro-ecological regions of south west India, and to characterize $D$. vexans by morpho-cultural methods.

\section{Materials \& Methods}

\section{Study area}

The study was carried out in six agro ecological zones of Karnataka, India for three years (2011-2013) (Fig. 1). The survey area covered approximately $1200-1350 \mathrm{~km}^{2}$ each year. The classification of the six agro-ecological zones is based on data provided by Indian Council of Agricultural Research, New Delhi and the Department of Agriculture, Government of Karnataka State.

\section{Severity assessment}

The severity of leaf blight and fruit rot disease was assessed by categorizing all the infected samples into different grades of infection using the grading scale 0-5 (McKinney 1923, Hossain et al. 2010). During 2011, 2012 and 2013, a total of 335, 370 and 342 fields, respectively, were surveyed in the six agro-ecological zones (AEZ). The disease severity in terms of per cent disease index (PDI) was calculated as,

$\mathrm{PDI}=($ Sum of numerical values/total number of leaves observed $\times$ maximum grading $) \times 100$.

Numerical values obtained by multiplying the number of infected leaves/fruits with their respective grades. Based on PDI, each locality was identified with the following grades. I - 0 PDI: free from the disease; II - 0.1-5.0 PDI: poorly affected; III - 5.1-20.0 PDI: moderately affected; IV - 20.1-50.0 PDI: severely affected; and V - >50.1 PDI: very seriously affected by the disease.

\section{Morphological and cultural identification of $D$. vexans}

Representative leaf blight and fruit rot samples collected from six AEZ were brought to the laboratory for isolation of the associated fungal pathogens (Dhingra \& Sinclair 1985). Samples were cut into small pieces $(5 \mathrm{~mm})$ and surface sterilized with $2 \%$ sodium hypochlorite solution for 2-3 min. followed by three washes with sterile distilled water. Samples were blotter dried and placed on potato dextrose agar (PDA) medium and incubated for 7 days at $28 \pm 2^{\circ} \mathrm{C}$. Fungal colonies expressed after 7 days of incubation were identified based on micro-morphology of vegetative structures, pycnidia and conidia. The fungal isolates were sub-cultured and stored at $4^{\circ} \mathrm{C}$ for further studies. The isolation frequency of $D$. vexans was determined by the number of samples having $P$. vexans and the total number of samples plated using the formula:

Isolation frequency $(D$. vexans $)=($ Number of samples having $D$. vexans $/$ Total number of samples plated) $\times 100$.

\section{Statistical analysis}

Data on severity from each agro-ecological zone were subjected arithmetic mean and SD calculated using the mean values for each study area. Dimensions were made for 50 conidia and the mean value is presented. 


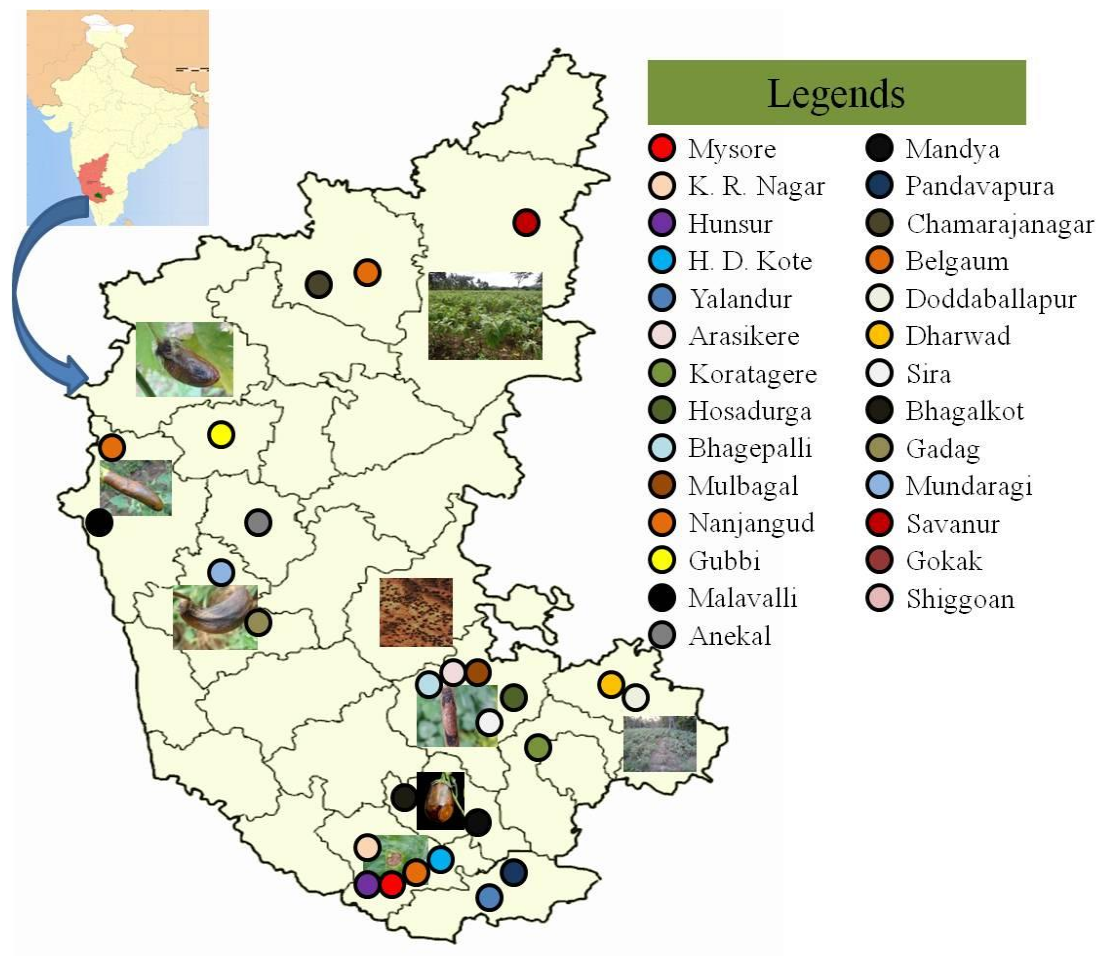

Fig 1 - Map of Karnataka showing the study localities visited to assess leaf blight and fruit rot disease severity in brinjal.

\section{Results}

The severity of leaf blight and fruit rot disease was determined (Figs 2, 3). The disease was prevalent $(100 \%)$ in all the studied regions. High severity of leaf blight $(15.2-53.7 \%)$ and fruit rot (41-78\%) was recorded in SDZ followed by NTZ (12.1-17.2\% -leaf blight disease). The lowest severity of leaf blight (3.8-12.8 and 8.4-34.2\%) and fruit rot (24-62 and 3.1-70) disease was observed in NTZ and STZ, respectively.

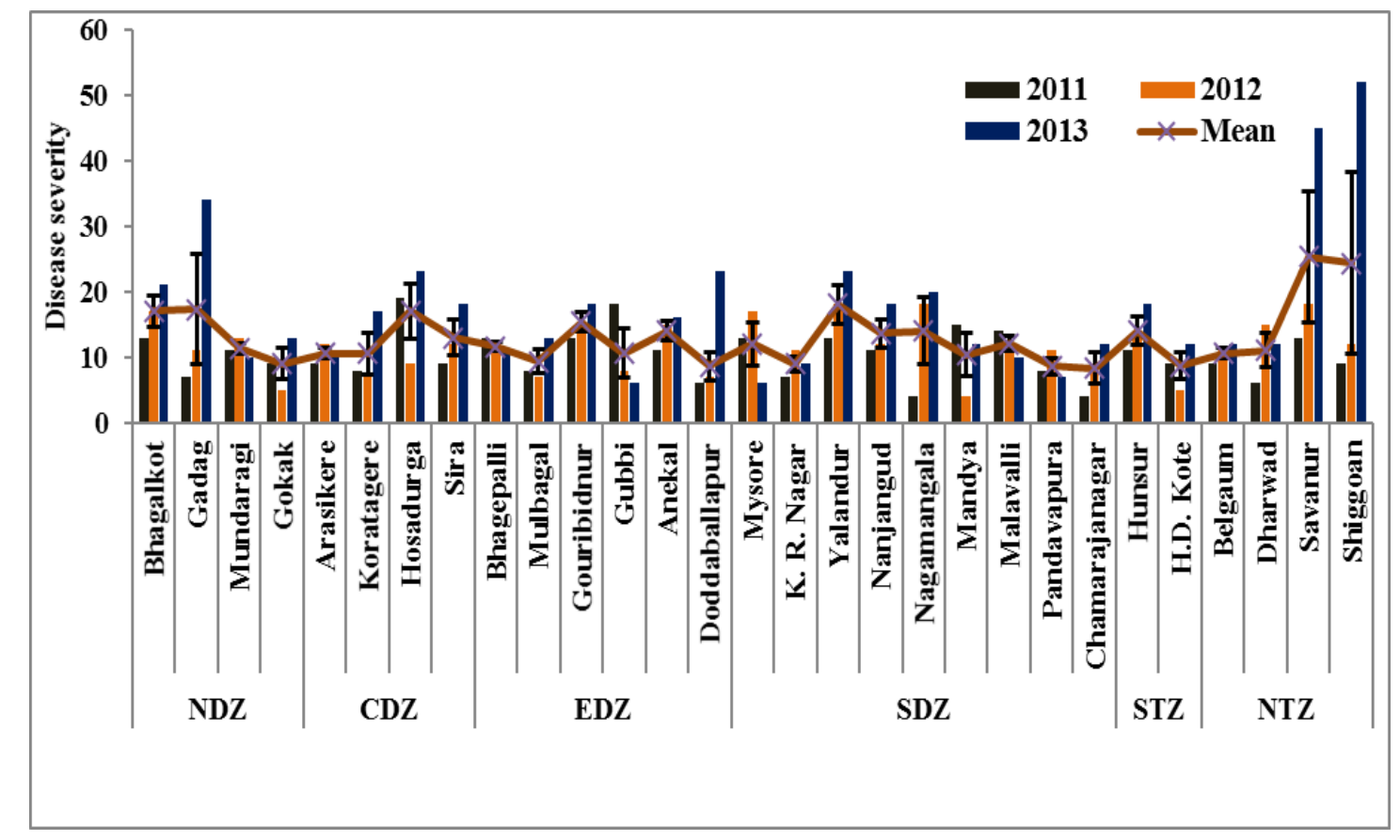

Fig 2 - Severity of leaf blight disease on brinjal from 2011-2013 in six agro-ecological regions of South West India. Bars represent the standard deviation for the mean values for each study area. 
In many zones, the incidence of fruit rot was very high when compared to leaf blight and it was responsible for severe fruit loss. The severity of leaf blight and fruit rot diseases varied from zone to zone and the severity differed in each year. Though there was difference between the severity of leaf blight and fruit rot disease, the leaf blight severity influenced the fruit rot severity as the inoculum load builds up as the crop reaches maturity.

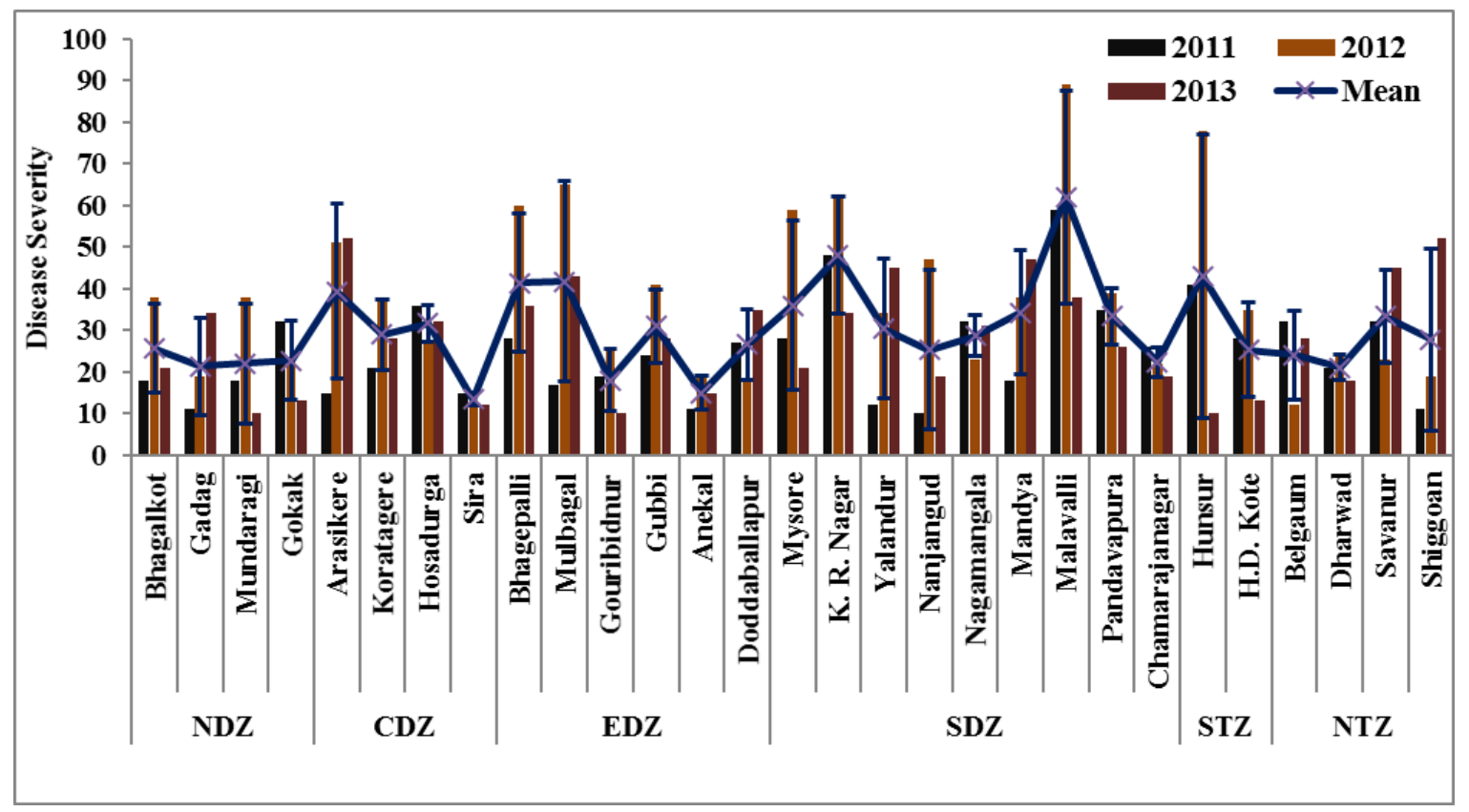

Fig 3 - Severity of fruit rot disease on brinjal from 2011-2013 in six agro-ecological regions of South West India. Bars represent the standard deviation for the mean values for each study area.

A total of 1007 samples of leaf blight, fruit rot and stem blight samples were collected across six AEZ; 921 samples were infected by D. vexans as evident on PDA isolation. The number of samples and isolation frequency of D. vexans is presented in Table 1 . The isolation frequency varied between different agro-ecological zones. Highest frequency of $D$. vexans was recorded from NDZ for leaf blight (94.73\%) and SDZ for fruit rot (95.83\%) disease. Stem blight disease was observed in EDZ, SDZ and STZ with 100\%, 89.47\% and 100\% (mean isolation frequency 95.54\%) isolation frequency, respectively.

Table 1 Isolation frequency of Diaporthe vexans from six agro-ecological regions

\begin{tabular}{llcccccc}
\hline $\begin{array}{l}\text { Sl. } \\
\text { No }\end{array}$ & \multicolumn{1}{c}{ Agro-Ecological Zone } & \multicolumn{3}{c}{$\begin{array}{c}\text { Number of Samples } \\
\text { collected* }\end{array}$} & \multicolumn{2}{c}{ Isolation Frequency } \\
\hline & & LB & FR & SB & LB & FR & SB \\
1 & Northern Dry Zone (NDZ) & 95 & 78 & NF** & 94.73 & 76.92 & - \\
2 & Central Dry Zone (CDZ) & 112 & 64 & - & 85.71 & 93.75 & - \\
3 & Eastern Dry Zone (EDZ) & 40 & 52 & 14 & 100 & 92.30 & 100 \\
4 & Southern Dry Zone (SDZ) & 118 & 96 & 38 & 91.52 & 95.83 & 89.47 \\
5 & Southern Transition Zone (STZ) & 64 & 46 & 34 & 100 & 100 & 100 \\
6 & Northern Transition Zone (NTZ) & 69 & 87 & - & 79.71 & 91.95 & - \\
& Overall & $\mathbf{4 9 8}$ & $\mathbf{4 2 3}$ & $\mathbf{8 6}$ & $\mathbf{9 0 . 9 6}$ & $\mathbf{9 1 . 2 5}$ & $\mathbf{9 5 . 5 4}$ \\
\hline
\end{tabular}

Note: LB-Leaf Blight; FR-Fruit Rot; SB-Stem Blight; *Value for total number of samples indicates the cumulative value for samples collected in survey period (2011-13); **NF-Not found 
Fruit rot symptoms appeared first as a minute sunken greyish spots with a brownish halo, which later enlarge and coalesce to form concentric rings of yellow and brown necrotic zones. The rotten areas increased in size and with the appearance of conidiomata concentric zones (Fig. 4).
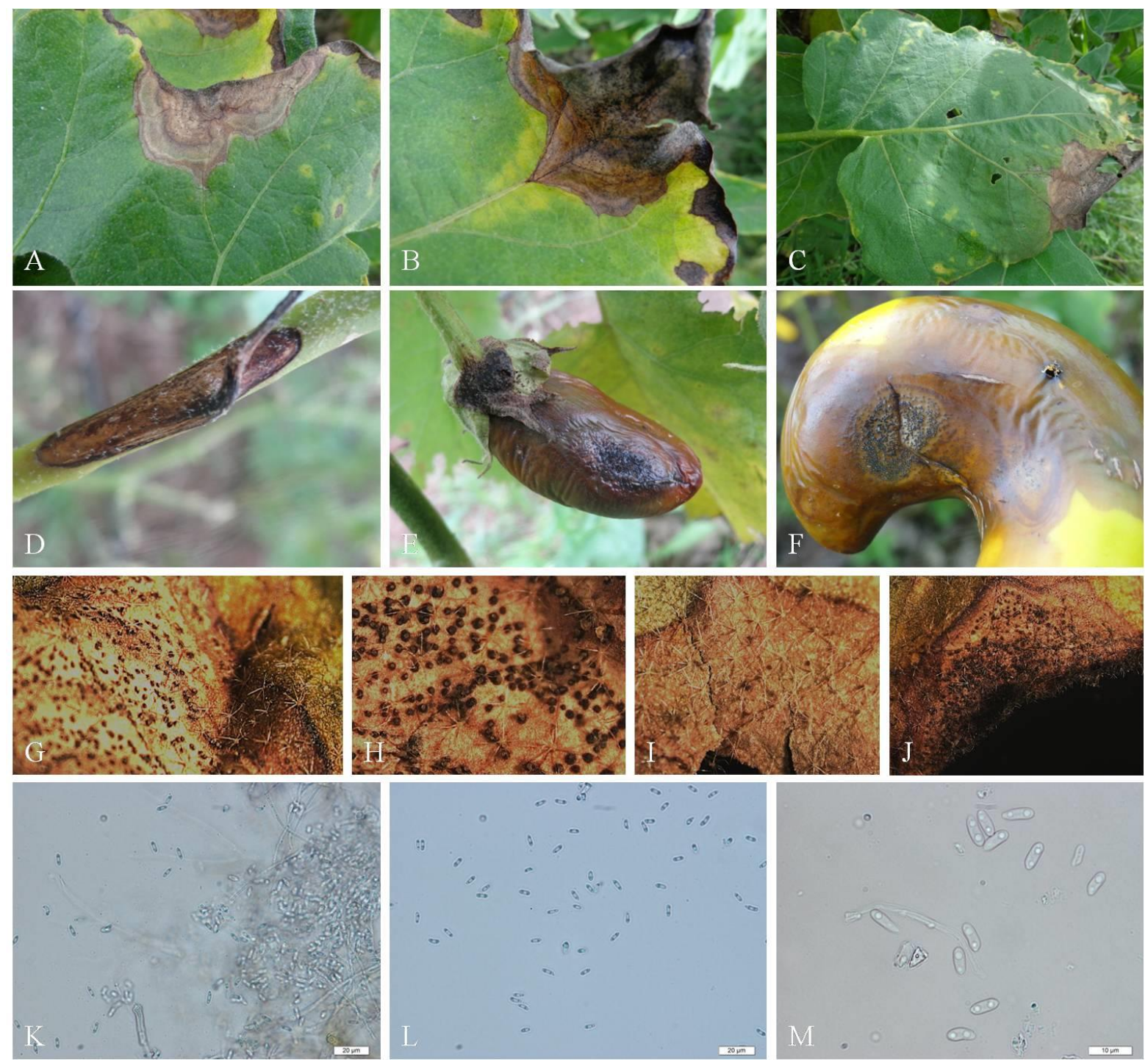

Fig 4 - Typical leaf blight and fruit rot disease symptoms on brinjal. A-C, Leaf blight symptoms. D, Stem blight symptom. E, F, Fruit rot disease. G-J, Pycnidia on necrotic leaves. K-M, Alpha conidia of $D$. vexans observed under compound microscope (Scale bars $=20 \mu \mathrm{m}$ ).

Colonies of $D$. vexans isolates on PDA were white to pale pink with wavy margins. Pycnidia were submerged and formed all over the surface of the mycelium (Fig. 5). The number and size of pycnidia varied from isolate to isolate. The mycelium was hyaline and septate; the conidiophores (phialides) within the pycnidium were hyaline, simple, or septate and arose from the innermost layer of cells lining the pycnidial wall. Two types of conidia (alpha and beta) were observed. Alpha conidia were hyaline, single celled, biguttulate and subcylindrical $(4.1-6.5 \times 1.2-1.9 \mu \mathrm{m})$. Beta conidia were filiform, curved, hyaline and septate $(6.2-7.6 \times 0.5-0.8 \mu \mathrm{m})$. 


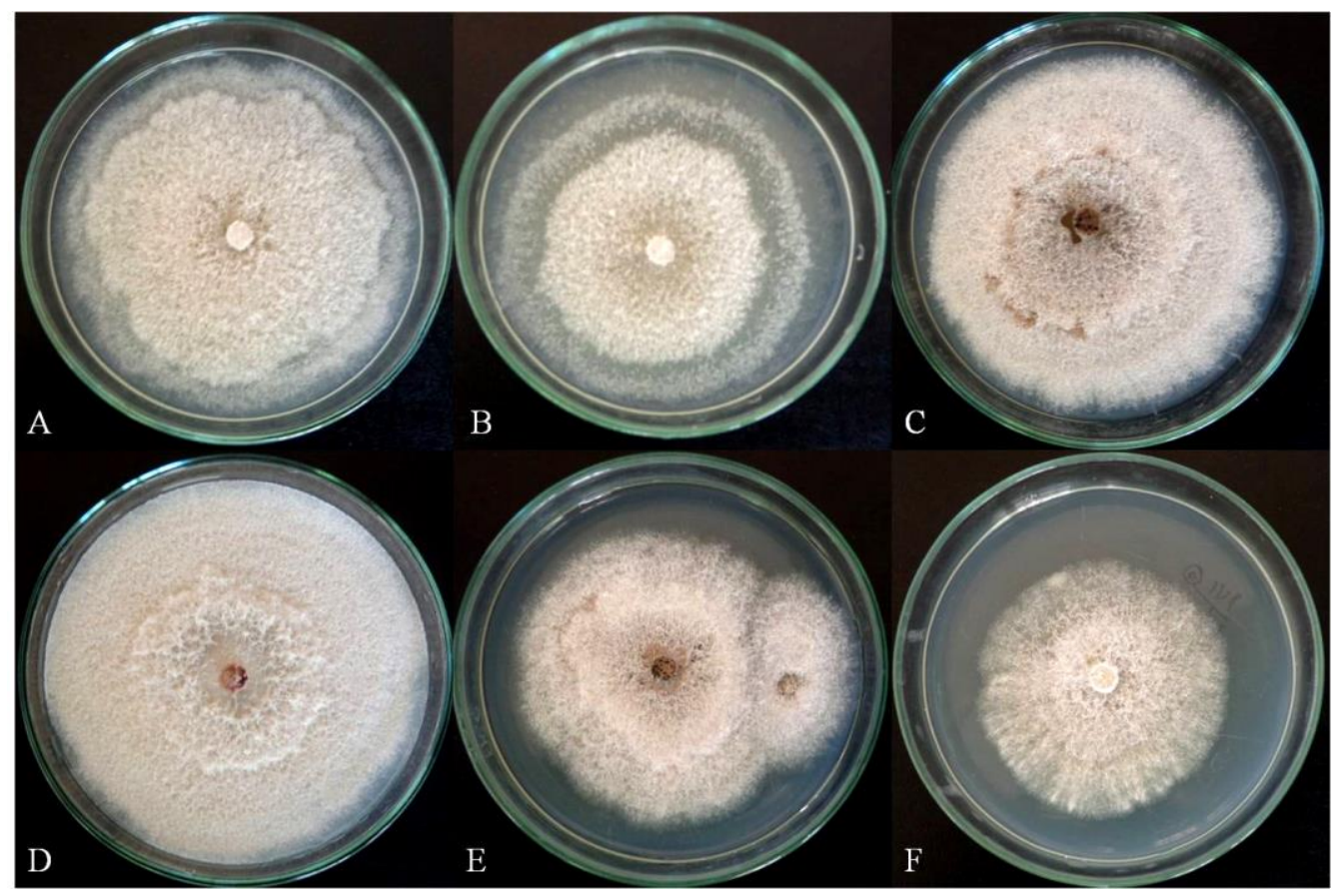

Fig 5 - Colony morphology of Diaporthe vexans (pure cultures on PDA) isolated from A, leaf blight disease; B, fruit rot disease; C, stem blight disease; D, infected seed; E \& F, damping-off disease.

\section{Discussion}

The brinjal crop is susceptible to both biotic and abiotic stresses during different stages of crop production. Among the biotic agents, fungal pathogens are responsible for significant reduction in crop yield. The most important and widespread fungal diseases are leaf blight and fruit rot (Diaporthe vexans), leaf spot (Alternaria melongenae and Cercospora melongenae), dampingoff (Pythium aphanidermatum), wilt (Verticillium dahliae) and root rot (Sclerotinia sclerotiorum) (Shivaprakasam \& Soumini Rajgopalan 1974, Iqbal et al. 2003).

A field survey conducted in UP (Mishra \& Mishra 2012), Karnataka (Jayaramaiah et al. 2013) and Allahabad (Singh et al. 2014) reported the occurrence of Diaporthe vexans but quantitative data is lacking. There are no reports assessing the severity of leaf blight disease. The incidence and severity of disease is greatly influenced by the weather conditions (Seem 1984) and cultural practices (sprinkling irrigation) adapted during crop cultivation. The splash dispersal of soil or fruit-borne conidia might have caused new infections resulting in high disease incidence in many zones.

Diaporthe vexans produces different disease symptoms such as damping-off, leaf blight, fruit rot and stem blight on brinjal crop. Damping-off of brinjal includes the development of girdling signs at the base of the stem and soil interface. The affected plants topple and die due to rotting of root system (Singh 1992). Pycnidia were noticed on the girdle and the death of whole seedling was observed. Leaves emerging from infected seedlings also showed leaf spot disease due to early infection. Leaf blight symptoms includes the development of tan or brown oval necrotic zones, which later become irregular and coalesce. Lesions on the petiole or the lower part of the midrib resulted in early senescence, and the blight affected areas produced numerous black pycnidia (Harter 1914, Jayaramaiah et al. 2013). At first, the lesions were small, more or less circular, and buff to olive, later becoming cinnamon buff, with an irregular blackish margins. Rotting of fruit was noticed during transit and even after harvest (Sherf \& MacNab 1986). On stems and aerial branches, elongated, blackish brown lesions were observed. The affected plants produced small leaves and the axillary buds were often killed. When stem girdling was severe, the shoots showed wilting followed by death of infected seedlings. Affected plants were toppled by the wind (Edgerton \& Moreland 1921, Pawar \& Patel 1957, Sherf \& MacNab 1986). Pycnidia were seen on 
lesions on young stems, but rarely on older ones (Harter 1914). Pycnidia on fruit were bigger than those produced on stems and leaves (Harter 1914). In severe infection, the whole fruit was mummified (Pawar \& Patel 1957).

In conclusion, the study indicated that $D$. vexans is distributed in all the six agro-ecological zones of southwest India and considerable crop loss was recorded in all zones. D. vexans was the predominant fungal pathogen associated with leaf blight and fruit rot disease. As the disease severity increased year after year in major brinjal growing regions, there is a need for screening and identifying disease resistant cultivars against leaf blight and fruit rot disease. This will be the long term strategy to prevent crop losses due to $D$. vexans infection.

\section{Acknowledgements}

S. Mahadevakumar would like to acknowledge the Department of Science and Technology (DST), New Delhi for providing INSPIRE Fellowship (IF110422).

\section{References}

Akhtar J, Chaube HS. 2006 - Variability in Phomopsis blight pathogen (Phomopsis vexans (Sacc. \& Syd.) Harter). Indian Phytopathology 59(4), 439-444.

Beura SK, Mahanta IC, Mahapatra KB. 2008 - Economics and chemical control of Phomopsis twig blight and fruit rot of brinjal. Journal of Mycopathological Research 46(1), 73-76.

Boddy L, Griffith GS. 1989 - Role of endophytes and latent invasion in the development of decay communities in sapwood of angiospermous trees. Sydowia 41, 41-73.

Botella L, Diez JJ. 2011 - Phylogenic diversity of fungal endophytes in Spanish stands of Pinus halepensis. Fungal Diversity 47, 9-18.

Carroll GC. 1986 - The biology of endophytism in plants with particular reference to woody perennials. In: Fokkema NJ, Heuvel J van den (eds), Microbiology of the Phyllosphere, 205222. Cambridge University Press, Cambridge.

Das BH. 1998. Studies on Phomopsis fruit rot of brinjal. M.S. thesis. Department of Plant Pathology, Bangladesh Agricultural University, Mymensingh.

Das SN, Sarma TC. 2012 - Some micro-fungi and their association on the incidence of diseases of brinjal (Solanum melongena L.) in Western Assam. The Bioscan 1, 303-306.

Dhingra OD, Sinclair JB. 1985 - Basic Plant Pathology Methods. CRC Press, Boca Raton, FL.

Edgerton CW, Moreland CC. 1921. Eggplant blight. Louisiana Agricultural Experiment Station Bulletin, 178, 1- 44.

Gomes RR, Glienke C, Videira SIR, Lombard L, Groenewald JZ, Crous PW. 2013 - Diaporthe: a genus of endophytic, saprobic, and plant pathogenic fungi. Persoonia 31, 1-41.

Harter LL. 1914 - Fruit-rot, leaf-spot and stem blight of the eggplant caused by Phomopsis vexans. Journal of Agricultural Research 2(5), 331-338.

Hossain TM, Hossain SMM, Bakr MA, Matiar, Rahman AKM, Uddin SN. 2010 - Survey on major diseases of vegetables and fruit crops in Chittagong region. Bangladesh Journal of Agricultural Research 35(3), 423-429.

Iqbal SM, Ghafoor A, Ahmad Z, Haqqani AM. 2003 - Pathogenicity and fungicidal efficacy for Sclerotinia rot of brinjal. International Journal of Agriculture and Biology 5(4), 618-620.

Jayaramaiah KM, Mahadevakumar S, Charithraj AP, Janardhana GR. 2013 - PCR based detection of Phomopsis vexans (Sacc. \& Syd.) - the causative agent of leaf blight and fruit rot disease of Brinjal (Solanum melongena L.). International Journal of Life Science 7(1), 17-20.

Khan NU. 1999. Studies on epidemiology, seed borne nature and management of Phomopsis fruit rot of brinjal. M.S. Thesis, Department of Plant Pathology, Bangladesh Agricultural University, Mymensingh, Bangladesh.

McKinney HH. 1923 - Influence of soil temperature and moisture on infection of wheat seedlings by Helminthosporium sativum. Journal of Agricultural Research 26, 195-210. 
Mishra AK, Mishra VK. 2012 - Field survey for some fungal diseases of eggplant. International Multidisciplinary Research Journal 2(9), 23.

Mostert L, Crous PW, Kang JC, Phillips AJL. 2001 - Species of Phomopsis and a Libertella sp. occurring on grapevines with specific reference to South Africa: morphological, cultural, molecular and pathological characterization. Mycologia 93, 146-167.

Muneeshwar S, Razdan VK, Sourav G. 2011 - Occurrence of Phomopsis leaf blight and fruit rot of brinjal caused by Phomopsis vexans in Jammu. Annals of Plant Protection Sciences 19(2), 396-399.

Murali TS, Suryanarayanan TS, Geeta R. 2006 - Endophytic Phomopsis species: host range and implications for diversity estimates. Canadian Journal of Microbiology 52, 673-680.

Pandey A. 2010 - Studies on fungal diseases of eggplant in relation to statistical analysis and making of disease calendar. Recent Research in Science and Technology 2(9), 1-3.

Pawar VH, Patel MK. 1957. Phomopsis blight and fruit rot of brinjal. Indian Phytopathology 10, 115-120.

Rashid MM. 1976 - Bangladesher Sabji. Ist edn., Bangla Academy, Dhaka.

Santos JM, Vrandečić K, Ćosić J, Duvnjak T, Phillips AJL. 2011 - Resolving the Diaporthe species occurring on soybean in Croatia. Persoonia 27, 9-19.

Seem RC. 1984 - Disease incidence and severity relationships. Annual Review of Phytopathology $22,133-150$.

Sekara A, Cebula S, Kunicki E. 2007 - Cultivated eggplants - origin, breeding objectives and genetic resources, a review. Folia Horticulturae 19(1), 97-114.

Sherf AF, McNab AA. 1986 - Vegetable Diseases and their Control. 2nd edn. New York, USA, John Wiley and Sons.

Shivaprakasam K, Soumini Rajagopalan CK. 1974 - Effect of nitrogen on the incidence of Verticillium wilt disease of egg plant caused by Verticillium dahliae Kleb. Plant and Soil 40, 217-220.

Singh BK, Singh S, Singh BK, Yadav SM. 2014 - Some important plant pathogenic diseases of brinjal and their management. Plant Pathology Journal 13(3), 208-213.

Singh RS. 1992 - Diseases of Vegetable Crops. 2nd edn. Oxford and IBH Publishing Company, New Delhi.

Smith IM, Dunez J, Lelliott RA, Phillips DH, Archer SA. 1988 - European Handbook of Plant Diseases. Oxford, UK, Blackwell Scientific Publications.

Srinivasa C, Niranjana SR, Shetty HS. 2006 - Effect of bio-agents and fungicides against Phomopsis vexans and on seed quality of brinjal. Crop Improvement 32(1), 95-101.

Thippeswamy B, Krishnappa M, Chakravarthy CN. 2005 - Location and transmission of Phomopsis vexans, Alternaria solani in brinjal. Indian Phytopathology 58(4), 410-413.

Thompson SM, Tan YP, Young AJ, Neate SM, Aitken EA, Shivas RG. 2011 - Stem cankers on sunflower (Helianthus annuus) in Australia reveal a complex of pathogenic Diaporthe (Phomopsis) species. Persoonia 27, 80-89.

Udayanga D, Liu X, McKenzie EHC, Chukeatirote E, Bahkali AHA, Hyde KD. 2011 - The genus Phomopsis: biology, applications, species concepts, and names of common phytopathogens. Fungal Diversity 50, 189-225.

Vishunavat, Kumar S. 1994 - Location of infection of Phomopsis vexans in brinjal seeds. Indian Journal of Mycology and Plant Pathology 24, 226.

Zeven AC, Zhukovsky PM. 1975 - Dictionary of Cultivated Plants and their Centres of Diversity. Wageningen. 